Journal of Southeast Asian

\title{
Book Review: Yang, K. (2017). The Making of Hmong America: Forty Years after the Secret War. Lexington Books.
}

Thong Vang

University of Minnesota - Twin Cities, vang2825@umn.edu

Follow this and additional works at: https://docs.lib.purdue.edu/jsaaea

Part of the Asian American Studies Commons, Asian History Commons, Education Commons, and the Ethnic Studies Commons

\section{Recommended Citation}

Vang, Thong (2020) "Book Review: Yang, K. (2017). The Making of Hmong America: Forty Years after the Secret War. Lexington Books.," Journal of Southeast Asian American Education and Advancement: Vol. 15 : Iss. 1, Article 5.

DOI: $10.7771 / 2153-8999.1216$

Available at: https://docs.lib.purdue.edu/jsaaea/vol15/iss1/5

This document has been made available through Purdue e-Pubs, a service of the Purdue University Libraries. Please contact epubs@purdue.edu for additional information.

This is an Open Access journal. This means that it uses a funding model that does not charge readers or their institutions for access. Readers may freely read, download, copy, distribute, print, search, or link to the full texts of articles. This journal is covered under the CC BY-NC-ND license. 


\title{
JSAAEA Journal of Southeast Asian American Education and Advancement
}

Vol. 15 Iss. 1 (2020)

\author{
WWW.JSAAEA.org
}

Book Review: Yang, K. (2017). The Making of Hmong America: Forty Years after the Secret War. Lexington Books. 192 pp. ISBN: 9781498546454.

\author{
Reviewed by \\ Thong Vang \\ University of Minnesota, Twin Cities
}

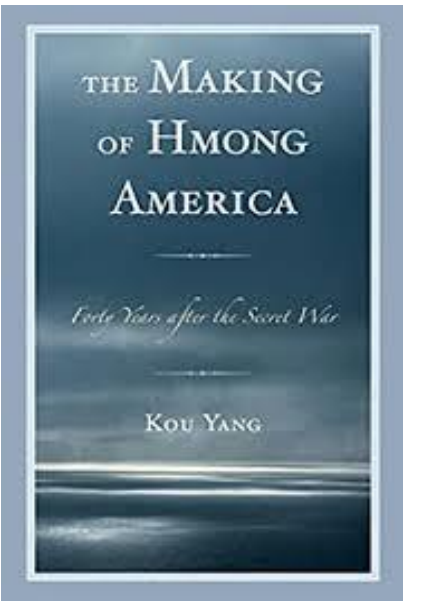

It has been forty-five years since the first wave of Hmong refugees arrived in the United States. The Hmong American diaspora was the result of the political conflicts in Southeast Asia between the 1950s up until a little over 1975. Since then, many of those who were involved have slowly made their way from Southeast Asia to other countries throughout the world. Among their Asian American counterparts, the Hmong and other Southeast Asians are among the newest waves of Asian immigrants to the United States. Unlike many other Asian Americans, they are still largely underserved and underrepresented in all economic industries.

As a 1.5 generation Hmong graduate student, I found The Making of Hmong America: Forty Years after the Secret War to be an important and critical text, both professionally and personally. As there were multiple waves of Hmong refugees, my family was part of the last few waves of resettlement to the United States. Even though each family's story varies, the Vietnam War and the Secret War continue to be salient among personal narratives in many Hmong refugee families.

The Making of Hmong America is part of a series of books and articles published by Dr. Kou Yang, highlighting the Hmong's involuntary migration from Asia to the rest of the world, their past status, and progress of the Hmong diaspora in the United States. The book expands upon a previous text that Yang had written entitled " 40 years after the Vietnam War: Celebrating the contributions of Indochinese refugees to the United States."

In the foreword along with the introduction, Yang chronologically and carefully lays out the purpose of the book and disputes the argument made by the United States and United Nation after the warring period that,

Hmong and other highlanders from Laos were considered by the U.S. government and its Congress as "not suitable for U.S. resettlement" ... [the] Hmong are a hill tribe people who would not be able to adapt and adjust to American society for survival (p. 54).

\section{(c)}

SDRERIIEHISRESEREEDReaders are free to copy, display, and distribute this article, as long as the work is attributed to the author(s) and the Journal of Southeast Asian American Education \& Advancement, it is distributed for non-commercial purposes only, and no alteration or transformation is made in the work. More details of this Creative Commons license are available at http://creativecommons.org/licenses/by-nc-nd/3.0/. All other uses must be approved by the author(s) or JSAAEA.

Journal of Southeast Asian American Education \& Advancement, Vol. 15. Iss. 1. (2020) ISSN: 2153-8999 
I felt that Yang did well with the way he organized the chapters to speak back to the deficit argument above. He pieces together biographies, personal communications, sensitive historical accounts, and past research to draw attention to the struggles and achievements of the Hmong in America. The first two chapters serve as an introduction to Hmong history and the development of the Vietnam War and Secret War while chapters three and four depict the transition and resettlement of the Hmong to the United States. Chapter five encompasses the state of Hmong in America along with a directory of Hmong professionals in different economic industries. Here is where Yang highlights the achievements and successes of Hmong Americans as a device to say, "Yes, we can adapt and we have done so in a way that has contributed to the U.S. economy and beyond." In the closing chapter, Yang adds that displacements and doubts by outsiders are not new to the Hmong:

In retrospect, the Hmong have been a people of diaspora for about five thousand years; their long history, as mentioned before, has been constant struggle through series of devastating wars, long migrations, oppressions, and suppressions by outsiders. The Hmong have been pushed and pulled to be displaced from ancient China into Southeast Asia, and lastly by crossing the Pacific Ocean to the Americas (p. 151).

This book celebrates the forty plus years which the Hmong have been in the United States and recognizes the challenges they have faced while acknowledging their achievements and contributions.

Yang nuances often orally-told narrative of the Hmong American journey throughout his book. For example, General Vang Pao is credited for the act of bringing "the Hmong to the United States"; however, Yang's account of Yang See's attempt to advocate for Hmong resettlement in the U.S. counters this narrative. Yang shows that it took more than one person to have made the resettlement of the Hmong people possible while underscoring the different oppositional figures that made the resettlement process difficult. These oppositional forces include the United States and United Nations, who were reluctant to recognize the Hmong as refugees because the Hmong are a minority group living in "neutral" Laos due to "both the 1954 and 1962 Geneva Accords" (p. 11). Neutrality meant that the United States and Hmong relationship during the Vietnam War was supposed to be kept a "secret," hence the "Secret War." With Laos being neutral, the institutions rationalized that the Hmong "were not like the Cambodian and the Vietnamese refugees who lost their countries after being militarily defeated by communists" (pp. 51-52).

Another oppositional figure, according to Yang, was General Vang Pao. He had scolded Yang See and his wife, Pia, for their advocacy on having the Hmong resettle in the United States. After having fled Laos, Yang See left Thailand for the United States and spoke with representatives of the U.S. Secretary of State, at the time, Henry Kissinger. This act was viewed as an opposition to General Vang Pao's plan of having the Hmong to return to Laos. I believe this is a sensitive claim because it introduces an alternative narrative to what has been said about General Vang Pao being the person "who brought the Hmong to the United States."

Yang's brief overview of educated Hmong people in Chapter three covers a group of young Hmong men who obtained college level education prior to 1975. In my opinion, I felt this chapter was short with only eight pages. There should have been more text covered because Yang notes that their education has contributed to the resettlement of the Hmong in America. One way to add on to the chapter is to detail the educational history of the other students as well and their 
whereabouts. Despite this limitation, this chapter illustrates that there were "educated" Hmong during a time where Hmong people were considered as an illiterate group of people and those educated played an instrumental role in the future direction of their Hmong community in Southeast Asia and the United States.

Strategically, Yang builds each chapter on the former to establish a linear historical context for the readers. It is in Chapter five, the longest chapter, that was the climax of the book. He addresses his argument of why the Hmong and other Southeast Asian refugees are suitable for life in America. Yang summarizes the Hmong in American experience with the Hmong proverb "If a small calf survives, it will be a bull, and if an orphan survives, she or he will be a woman or a man" (p. 76). This quote signifies the Hmong in America and around the world, after years of struggling through war, displacement, and prejudice and discrimination if given a chance they will survive and thrive.

Chapter five documents the contributions of Hmong Americans since their first arrival. The strength in this chapter is Yang's catalogs of economic and educational progression of the Hmong American communities throughout the nation, covering Hmong in different professions across industries, such as, art and literature, business entrepreneurship, corporate America, education, high tech and service, Hollywood and the filmmaking industry, law, political participation, and other contributions. While I felt the chapter could be further expanded, I found this section to be inspiring, and of course, I also understand the elaboration of these individual narratives may not be the purpose of the chapter and of the book. Nevertheless, it would be wonderful to hear more about these individuals' work and lives.

Interestingly, I noticed most stories and interviews in the book were male centric. This is prevalent in Hmong folk stories and oral history that the narrative focus on male figures. Generations have gone by along with the war-era generation, the stories of grandmothers, sisters, mothers, daughters, granddaughters, and so forth were also impacted by the war, and their stories would have added dynamic to the overall narrative of the Hmong American journey and experience. Moving forward, how should the Hmong youth generation best capture the voices and stories of the whole Hmong community, so it does not only center men?

While I recognize the setbacks of the book being male centric, I also see that Yang is introducing men who were not originally credited for their contributions for paving the way to the United States. I found their contributions important for our community to know. I do appreciate Yang's positionality and relationship which provided him access to people who may not be accessible to me or others. However, I want to not only critique but also encourage more historical accounts of others and to consider the spectrum of what makes up the Hmong refugees and Hmong American experiences.

Lastly, Yang's book plays an important role in the larger Hmong American community context. Historically, Yang's work provides knowledge that is not readily available to the community-at-large and sometimes even to those who are Hmong, such as those who were born or raised in the United States. Later generation Hmong youth can pick up this book and read about what happened to the larger Hmong community before arriving in the United States. It is a text that speaks back to deficit discourses of refugee and immigrant communities.

Overall, I believe Yang's complications of our shared Hmong narrative push for dialogues and discussions among Hmong and other communities as we try to unpack the historical narratives which unfolded before, during, and after the Secret War. I recommend reading this book for members of the Hmong community, professionals, and academics alike, to understand the history of a refugee community in the United States and the transition challenges faced by communities 
who are stateless. I would like to take it a step further and suggest that it be taught and read in Hmong and Southeast Asian history courses as a way of challenging the dominant narratives told in the Hmong and academic community.

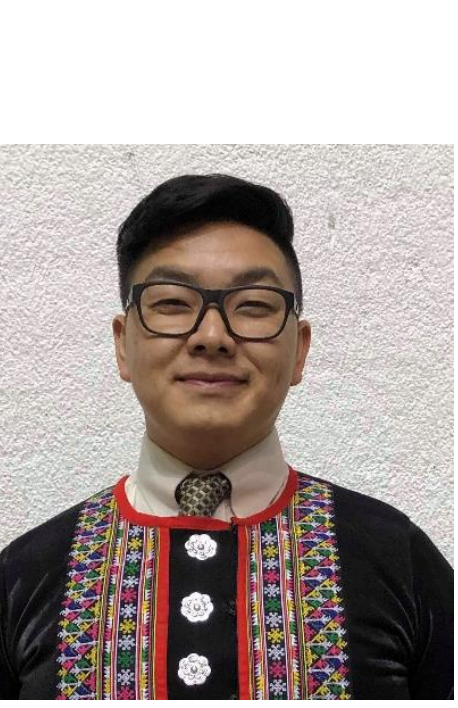

\section{About the Author}

Thong Vang, is a Ph.D. student in the Culture and Teaching program at the University of Minnesota-Twin Cities. His research interests are in identity development of diasporic Southeast Asian communities, and Hmong cultural learning and teaching practices. More specifically, he examines how marginalized communities combat deficit models of academic identities. Currently, he serves as a graduate assistant with the Asian Pacific American Resource Center (APARC) at the University of Minnesota and as a research assistant with Lub Zej Zog Hmong Education Project at the University of Wisconsin-Whitewater. 


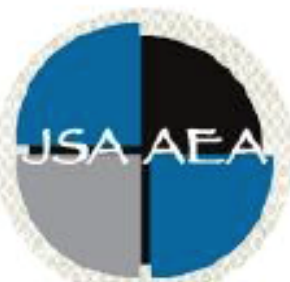

Vol.15 Iss.1 (2020)

\title{
Journal of Southeast Asian American Education and Advancement
}

\author{
Www.JSAAEA.org
}

\section{Editor}

Dr. Wayne E. Wright

Purdue University

Associate Editors

Dr. Chhany Sak-Humphry

University of Hawaii at Manoa

Dr. Phitsamay Sychitkokhong Uy

University of Massachusetts, Lowell

\author{
Book Review Editor \\ Dr. Vichet Chhuon \\ University of Minnesota \\ Creative Works Editor \\ Bryan Thao Worra \\ Lao Assistance Center \\ Journal Manager \\ Fang Gao \\ Purdue University
}

Editorial Review Board

\author{
Dr. Steve Arounsack \\ California State University, Stanislaus \\ Dr. Sovicheth Boun \\ Salem State University \\ Dr. Virak Chan \\ Purdue University \\ Dr. Loan Dao \\ University of Massachusetts Boston
}

\author{
Dr. Carl L. Bankston III \\ Tulane University \\ Dr. Phala Chea \\ Lowell Public Schools \\ Dr. George Chigas \\ University of Massachusetts, Lowell \\ Dr. Hien Duc Do \\ San Jose State University
}




\author{
Dr. Changming Duan \\ University of Missouri-Kansas City \\ Dr. Sothy Eng \\ Lehigh University \\ Dr. Vincent K. Her \\ University of Wisconsin, Eau Claire \\ Dr. Peter Nien-Chu Kiang \\ University of Massachusetts, Boston \\ Dr. Kevin K. Kumashiro \\ University of Illinois, Chicago \\ Dr. Ha Lam \\ Independent Scholar \\ Dr. Jonathan H. X. Lee \\ San Francisco State University \\ Dr. Monirith Ly \\ Royal University of Phnom Penh \\ Dr. Bic Ngo \\ University of Minnesota \\ Dr. Leakhena Nou \\ California State University, Long Beach \\ Dr. Mark Pfeifer \\ SUNY Institute of Technology \\ Dr. Loan T. Phan \\ University of New Hampshire \\ Dr. Karen Quintiliani \\ California State University, Long Beach \\ Dr. Angela Reyes \\ Hunter College \\ The City University of New York \\ Dr. Fay Shin \\ California State University, Long Beach \\ Dr. Christine Su \\ College of San Mateo \\ Dr. Alisia Tran \\ Arizona State University \\ Dr. Khatharya Um \\ University of California, Berkeley \\ Dr. Kim Tran \\ University of California, Los Angeles, \\ Glendale Community College \\ Dr. Molly Wiebie \\ The University of Texas at Austin
}

Dr. Sophal Ear

Occidental College

Dr. Jeremy Hein

University of Wisconsin, Eau Claire

Dr. Nancy H. Hornberger

University of Pennsylvania

Dr. Peter Tan Keo

New York University

Dr. Yvonne Kwan

San Jose State University

Dr. Ravy Lao

California State University, Los Angeles

Dr. Stacey Lee

University of Wisconsin, Madison

Dr. Sue Needham

California State University, Dominguez Hills

Dr. Max Niedzwiecki

Daylight Consulting Group

Dr. Clara Park

California State University, Northridge

Dr. Giang Pham

University of Massachusetts Amherst

Dr. Malaphone Phommasa

University of Clifornia Santa Barbara

Dr. Kalyani Rai

University of Wisconsin-Milwaukee

Dr. Cathy J. Schlund-Vials

University of Connecticut, Storrs

Dr. Nancy J. Smith-Hefner

Boston University

Dr. Yer J. Thao

Portland State University

Dr. Monica M. Trieu

Purdue University

Dr. Silvy Un

Saint Paul Public Schools

Dr. Linda Trinh Vo

University of California, Irvine

Dr. Yang Sao Xiong

The University of Wisconsin-Madison

Dr. Zha Blong Xiong

University of Minnesota 


\section{Doctoral Student Editorial Review Board}

\author{
Linh Dang \\ University of Rochester \\ My-Lan Huynh \\ California State University East Bay \\ Jacqueline Mac \\ Indiana University \\ Hoa Nha Nguyen \\ Boston College \\ Thien-Huong Ninh \\ University of Southern California \\ Latana Thaviseth \\ University of California Los Angeles \\ Mai Vang \\ University of Massachusetts Boston \\ Soua Xiong \\ San Diego State University \\ Claremont Graduate University
}

\author{
Annie BichLoan Duong \\ San Joaquin County Office of Education \\ Vanessa Sovanika Na \\ University of California SanDiego \\ Dung Minh Mao \\ University of Minnesota \\ Khoi Nguyen \\ George Mason University \\ Linda Marie Pheng \\ University of Wisconsin-Madison \\ Krissyvan Truong \\ Claremont Graduate University \\ Melissa Vang \\ San Diego State University
}

